\title{
Pornografi dan Pornoaksi Persiektif Hukum Islam
}

\author{
Shohibul Adib \\ Mahasiswa Pascasarjana Universitas Islam Negeri [UIN] \\ Sunan Kalijaga Program Studi Islamic Studies \\ adib2279@gmail.com
}

\begin{abstract}
The progress of science and technology that can not be avoided, print and electronic media and the potential to contribute greatly to the spread of the problem and pornoaksi and pornografi. The results of this study show three subjects. First, in the $16^{\text {th }}$ century, the roots of pornography in the Western world is considered as a balance between the political and sexual. Pornography share the progress with the development of civilization and modern technology. Second, the discussion of the perspective of Islamic law against pornography use two approaches, namely the normative and juridical approach. From the normative refers to the two main sources of Islam, namely the Qur'an and Sunnah to see the Quranic verses and hadiths of the Prophet related to pornography. While the juridical explanation will refer to the MUI fatwa and the Law of the Republic of Indonesia No. 442008 on pornography. Third, pornography and porno-action perspective of Islamic law are forbidden, it is clearly a normative based on several verses in the Qur'an. And some of the traditions of the Holy Prophet are strictly prohibited.
\end{abstract}

Keywords: Pornography, Islamic Law Perspective 


\section{Pendahuluan}

Allah menciptakan manusia dibekali dengan berbagai kecenderungan, harta, lawan jenis, anak-anak dan sebagainya (QS.3;14), dan potensi berbuat baik dan potensi berbuat kedurhakaan (QS.91;8). Islam sebagai agama paripurna, telah menjelaskan dan mengatur dengan segala permasalahnnya, baik manusia sebagai khalifah maupun sebagai hamba Allah swt. Adanya pengaturan (syariat) Tuhan adalah untuk mewujudkan kemaslahatan bagi umat manusia. Keanekaragaman potensi yang dimiliki manusia, baik berupa akal, emosi maupun fisik akan semakin meningkat menjadi lebih baik dan fungsional disebabkan proses belajar yang dialami manusia melalui pengaruh lingkungan sosialnya. Implikasi kedua hal tersebut adalah berpengaruh secara langsung dan menentukan kecendrungan, watak, karakter dan perilaku manusia.

Pornografi dan pornoaksi yang marak dibicarakan dan menyita perhatian ${ }^{1}$ banyak kalangan merupakan bagian dari akumulasi lingkungan yang cenderung menjadi budaya dan terpelihara, dan juga sekaligus efek globalisasi yang tengah berlangsung saat ini. Kemajuan IPTEK yang tidak dapat dihindari, media (cetak dan elektronik) sangat memberi kontribusi dan potensial dalam penyebaran masalah pornografi dan pornoaksi. Selanjutnya dalam konteks historis, pornografi dan porno aksi mungkin setua peradaban umat manusia. Akan tetapi, literatur yang mendukung pandangan semacam ini sulit ditemukan, paling tidak terbatas pada mitos atau legenda yang menggambarkan fenomena pornografi dalam kehidupan nenek moyang kita sejak nabi Adam dan Hawa. Sejarah pornografi di dunia Barat lebih banyak mengacu pada zaman renaisan, zaman pencerahan dan revolusi Prancis. Pada abad ke-16 akar pornografi di dunia Barat dianggap sebagai keseimbangan antara bidang politik dan seksual. ${ }^{2}$ Bagi kalangan penggemar porno-

1 Demikian menarik perhatian masyarakat, Presiden Susilo Bambang Yudoyono membentuk Satuan Tugas (Satgas) pornografi dan pornoaksi pada tanggal 16 Maret 2012.

2 Majelis Tarjih dan Pengembangan Pemikiran Islam, Pornografi dan Pornoaksi, 
grafi dan pornoaksi, seringkali dipandang sebagai perwujudan rasa kasih dalam diri makhluk hidup, sesuatu yang wajar, sehingga tidak perlu dipersoalkan. ${ }^{3}$ Tetapi, Islam memandang semacam ini tidak sepenuhnya dapat dibenarkan terutama dalam pandangan hukum. Terlebih lagi ketika masalah pornografi dan pornoaksi dilihat dari sisi efeknya yang secara empiris menimbulkan persoalan-persoalan hukum, misalnya kriminal, pemerkosaan.

Pada sisi lain, pornografi dan pornoaksi merupakan fenomena sosial yang muncul pada setiap masyarakat dan negara yang membangun dirinya dengan sistem ekonomi pasar. Hal tersebut mengindikasikan bahwa pornografi dan pornoaksi tidak bias dihilangkan secara total. Akan tetapi bukan berarti membiarkan masyarakat hidup dalam selera rendah dengan sajian-sajian media yang mempertontonkan eksploitasi tubuh, baik yang berbentuk gambar maupun tulisan. Berdasarkan uraian di atas, dapat dikemukakan rumusan masalah sebagai berikut; Pertama, bagaimana sejarah pornografi dan pornoaksi? Kedua, bagaimana pandangan hukum Islam terhadap pornografidan pornoaksi?

\section{Sejarah Pornografi dan Pornoaksi}

Menurut bahasa pornografi berasal dari bahasa Yunani porne yang berarti perempuan jalan dan grafein yang berarti menulis. ${ }^{4}$ Dari pengertian ini menunjukkan bahwa objek utama dan sumber pornografi adalah perempuan. Porno juga bermakna cabul, pornografi berarti penggambaran tingkah laku secara erotis dengan lukisan atau tulisan untuk membangkitkan nafsu birahi. ${ }^{5}$ Secara terminologi terdapat beberapa pengertian yang dikemukakan para ahli dan dirumuskan dalam UU Pornografi (UU RI N0. 44 Thn. 2008).

edisi V Januari 2003, h. 1.

3 Ibid, h. 3.

4 M. Sa’abah, Perilaku Seks Menyimpan dan Seksualitas Kontemporer Umat Islam (Jakarta: UI Press, 2001), h. 64.

5 Departemen Pendidikan Nasional, Kamus Besar Bahasa Indonesia, edisi III (Jakarta: Balai Pustaka, 2005), h. 889. 
Pornografi didefinisikan oleh Ernst dan Seagle sebagai berikut: "Pornography is any matter or thing exhibiting or visually repseresenting persons or animals performing the sexual act, whether normal or abnormal. (Pornografi adalah berbagai bentuk atau sesuatu yang secara visual menghadirkan manusia atau hewan yang melakukan tindakan sexual, baik secara normal ataupun abnormal). Oleh karena itu istilah pornografi mengandung pengertian hal-hal yang bersifat sexual. Peter Webb sebagai dikutip Rizal Mustansyir ${ }^{6}$ melengkapi definisi pornografi dengan menambahkan bahwa ponografi itu terkait dengan obscenity (kecabulan) lebih daripada sekedar erotis. Kemudian dalam perkembangan terbaru pornografi dipahami dalam tiga pengertian: Pertama, kecabulan yang merendahkan derajat kaum wanita. Kedua, merosotnya kualitas kehidupan yang erotis dalam gambar-gambar yang jorok, kosakata yang kasar, dan humor yang vulgar. Ketiga, mengacu pada tingkah laku yang merusak yang terkait dengan mental manusia. ${ }^{7}$

Pengertian yang ketiga sesungguhnya sudah terkait dengan pornoaksi ${ }^{8}$, karena terkait dengan tindakan yang mengarah pada hal-hal yang merusak melalui aktivitas seksual, baik secara kontak person yang bersifat liar (perbedaan antar jenis, sesama jenis) maupun melalui penyelenggaraan badaniah. Kontak seksual yang bersifat liar dalam hal ini berarti tanpa melalui prosedur yang lazim (pernikahan), atau dalam bahasa agama lebih dikenal dengan istilah zina. Sedangkan menurut Undang-Undang RI No. 44 Tahun 2008 tentang pornografi, didefinisikan bahwa pornografi adalah gambar, sketsa, ilustrasi, foto, tulisan, suara, bunyi, gambar bergerak, animasi, kartun, percakapan, gerak tubuh, atau bentuk pesan lainnya melalui berbagai bentuk media komunikasi dan atau pertunjukan di muka umum, yang memuat kecabulan atau eksploitasi seksual yang melanggar norma kesusilaan dalam ma-

\footnotetext{
${ }^{6}$ Lihat Rizal Mustansyir dalam Majelis Tarjih, op. cit. h. 2.

7 Ibid.

8 Untuk lebih jelas pengertian pornoaksi adalah tingkah laku secara erotis yang mengundang berahi. Lihat.Departemen Pendidikan Nasional, loc.cit.
} 
syarakat. ${ }^{9}$ Hemat penulis pengertian terakhir ini lebih kompleks karena mengakomodir beberapa defenisi yang ada. Selanjutnya dalam perspektif Islam, segala sesuatu yang mengarah pada zina adalah dilarang. Oleh karena itu, secara alamiah, manusia dengan hal-hal yang porno sangat potensial mengarah pada zina. Firman Allah swt. dalam Alquran surah al-Isra'/ 17; 32

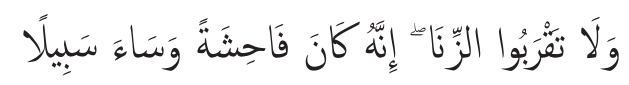

Artinya:

Dan janganlah kamu mendekati zina; sesungguhnya zina itu adalah suatu perbuatan yang keji. Dan suatu jalan yang buruk..$^{10}$

Pornografi dan Pornoaksi barangkali setua sejarah peradaban umat manusia di bumi, akan tetapi literatur yang mendukung pandangan semacam itu sulit ditemukan, paling tidak hanya sebatas mitos dan legenda yang menggambarkan fenomena pornografi dalam kehidupan nenek moyang kita sejak Nabi Adam dan Hawa. Sejarah pornografi di dunia Barat lebih banyak mengacu pada zaman renaisan, zaman pencerahan dan revolusi Francis. Pada abad ke-16 akar pornografi di dunia Barat dianggap seb lagai keseimbanvgan antara bidang politik dan seksual.

Pada abad ke 16, Aretino, seorang seniman Itali di zaman renaisan membuat sebuah karya termasyhur yang berjudul I Modi melibatkan tiga seniman tenar di zaman renaisan yaitu Aretino, Guiulo Romano dan Marcantonio Raimondi. Mereka melukis 16 gambar pada dinding gedung di Vatikan. Ke 16 gambar tersebut mencerminkan berbagai adegan seks yang mengundang reaksi keras dari pihak geraja pada waktu itu yaitu pope Clement VII. Tujuan utama Aretino mempublikasikan I Modi ada dua. Pertama, untuk menggambarkan adegan seks secara hidup dan sesuai dengan istilah pergaulan. Kedua, untuk mengejek

\footnotetext{
9 UU RI No. 44 Tahun 2008 Tentang Pornografi (Jakarta: Asa Mandiri, 2008), h. 2

${ }^{10}$ Depertemen Agama RI, Alquran dan Terjemahnya (Semarang: PT. Karya Toha Putra, 2002), h .386.
} 
pengadilan Agama yang terlibat korupsi. Karya Aretino ini dalam pandangan gereja Katolik telah memanfaatkan seks untuk mengekspos kasus korupsi di kalangan elit. ${ }^{11}$

Aretino juga mengemukakan konsep radikal lainnya dengan membangkitkan suatu gambaran utopis duniawi, yaitu sebuah dunia seks yang tidak terbatas dan menganut berbagai kemungkinan diungkapkan hasrat kaum wanita untuk lelaki. Karya ini merupakan sebuah bentuk kebebasan cinta dan refleksi suatu kekuatan yang memenatang penindasan gereaj, kosa kata yang bercorak eufimisme, seperti prick (tusukan) dan fuck (persetan) banyak dipergunakan untuk mengekspresikan kebebasa dari dogma agama yang dipandang mengikat atau membatasi. Melalui I Modi, Aretino menjadikan pornografi terkait erat dengan bidang politik dan bidang agama. Pengaruh Aretino dalam perkembangan pornografi tidak berakhir dengan I Modi ia masih mempublikasikan sebauah karya yang berjudul Ragionamentri atau discussion pada tahun 1539, yang isinya membicarakan tentang masalah-masalah seksual diantara wanita pelacur ibu rumah tangga dan biarawati. Pornografi di Inggris, dipaparkan oleh Rochester yang menggambarkan kehidupan seks di kalangan istana. Di Rusia, pornografi berkembang sejak Glasnot dan perubahan politik yang menggambarkan ledakan pornografi pasca komunis.Para femenis Barat mengasosiasikan ledakan pornografi di Rusia berdampak pada kekerasan domestik, pelecehan terhadap kaum wanita dan eksploitasi seksual wanita-wanita Rusia di tempat kerja. ${ }^{12}$

\section{Perspektii Hukum Islam mengenai Pornografi dan Pornoaksi}

Penjelasan mengenai perspektif hukum Islam terhadap pornografi dan pornoaksi, akan dikemukakan dua pendekatan; yaitu pendekatan normatif dan pendekatan yuridis. Dari sisi normatif akan dikemukakan dengan merujuk pada pada dua sumber pokok ajaran Islam, yaitu Al-

\footnotetext{
${ }^{11}$ Majelis Tarjih dan Pengembangan Pemikiran Islam, loc.cit.,

${ }^{12}$ Ibid.
} 
quran dan Sunnah dengan melihat ayat-ayat Alquran dan hadis-hadis Nabi saw. yang berhubungan dengan pornografi dan pornoaksi. Sementara sisi yuridisnya penjelasan akan mengacu pada fatwa MUI dan Undang-Undang Republik Indonesia N0. 44 Tahun 2008 tentang pornografi.

\section{Pendekatan Normatii}

Dalam Alquran, paling tidak ada tiga ayat, yaitu; (QS.al-A'raf/7:26, QS.al-Isra/17:32, QS.al-Nur/24:30) yang dapat dipahami sebagai petunjuk mengenai larangan pornografi dan pornoaksi.

Al-quran surah al-Isra' ayat 32 telah tegas melarang mendekati zina apalagi berbuat zina. Menurut Ahmad Musthafa al-Maraghi dalam Tafsir al-Maraghi jika zina terjadi akan kacau nasab dan terjadi perang sesama manusia karena mempertahankan kehormatan ${ }^{13}$, juga akan merusak moral masyarakat dan mendatangkan penyakit, ${ }^{14}$ sedang pada surah al-Ahzab ayat 59 berbicara tentang perintah menutup aurat dengan memakai jilbab. Menurut Thabathaba'I sebagai dikutip M. Quraish Shihab, makna kata jilbab adalah menutup seluruh badan termasuk kepala dan wajah perempuan. ${ }^{15}$ Sementara pada surah al-A'raf ayat 26 Allah swt memerintahkan menutup aurat dengan perintah dan bahasa yang lebih komprehensif yakni pakaian taqwa. Thahir Ibnu Asyur, memahami bahwa pakaian taqwa merupakan pakaian lahir batin, berperan memelihara kesucian dan kehormatan manusia. ${ }^{16}$ Penjelasan ayat terakhir ini juga dijelaskan dalam tafsir al-Azhar, bahwa

\footnotetext{
${ }^{13}$ Lihat Ahmad Musthafa al-Maraghi, Tafsir al-Maraghi (Mesir: Mustafa al-Babi alHalabi, 1394 H /1974 M), h. 57.

${ }^{14}$ Syekh Muhammad al-Gazali, A Thematic Commentary on The Qur'an,; Kuala Lumpur-Islamic Book Trust, The International Institute of Islamic Thaught, 2000), h. 289.

${ }^{15}$ Lihat M. Quraish Shihab, Tafsir al-Mishbah Vol. 11 (Cet. V; Jakarta: Lentera Hati, 2006), 321.

${ }^{16}$ Lihat Ibid., Vol. 5, h. 60.
} 
taqwa itu sendiri adalah pakaian. ${ }^{17}$

Selanjutnya, larangan Islam atas pornografi, dapat dilhat pada beberapa hadis sebagai berikut ini;

حد ثنا زكريا بن عدي قال حد ثنا عبيد الله بن عمر و عن عبد الله بن محمد بن

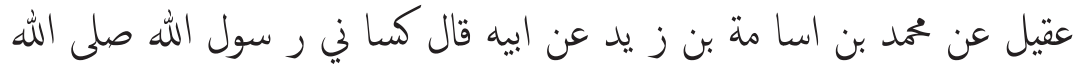

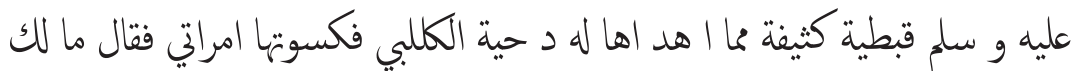

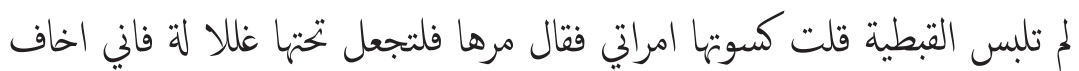
ان تصف ججم عظامها

Artinya:

Dari Ibnu Usamah bin Zaid bahwa ayahnya Usamah berkata; Rasulullah Saw memberikan kepadaku jenis pakaian rangkap luar yang tembus pandang berwarna putih buatan Mesir yang dihadiahkan Dihyah al-Kalbi. Kemudian aku berikan kepada istriku (untuk dipakai). Rasulullah Saw bertanya kepadaku; mengapa kamu tidak menggunakan qubthiyah itu? Aku menjawab; Aku berikan (sebagai pakaian) istriku. Rasulullah Saw bersabda kepadaku; suruh istrimu agar mengenakan rangkap dalam (karena) aku khawatir pakaian tersebut memperlihatkan bentuk tubuhnya (HR.Ahmad) ${ }^{18}$

عن عا سُشة رضي الله عنها ان ا سلاء بذت ابي بكر دخلت علي رسو ل الله صلي

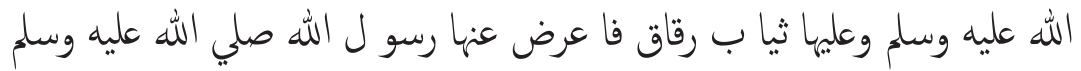

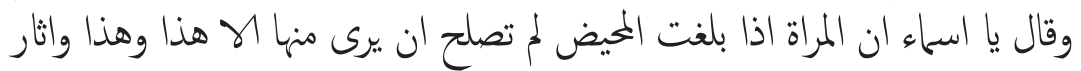
الي وبجه وكفيه قال ابو داود هذا مرسل خالد بن دريك لم يدرك عائشة رضي الله

Artinya:

Dari Aisyah r.a bahwa Asma binti Abu Bakar masuk ke rumah Rasulullah seraya memakai pakaian tipis lalu Rasulullah ber-

${ }^{17}$ Lihat Hamka, Tafsir Al-Azhar, juz VIII (Cet. III; Jakarta: PT. Pustaka Panjimas, 1999), h.198.

${ }^{18}$ CD ROM. Hadis Kutub Tis'ah, Riwayat Ahmad no. 20789. 
paling dari arahnya dan bersabda: seorang perempuan jika telah sampai usia dewasa tidak terlihat dari tubuhnya kecuali ini dan ini. Beliau menunjuk ke muka dan kedua telapak tangannya (HR. Abu Dawud $)^{19}$

Secara tersurat kedua hadis tersebut, berisikan dua hal penting. Pertama, larangan menggunakan pakaian tembus pandang, Kedua, larangan terhadap laki-laki untuk memandang aurat perempuan. Sesuai dengan defenisi pornografi kedua hadis tersebut menyebut telanjang sebagai salah satu faktor munculnya larangan. Apabila telanjang tidak dimaksudkan sebagi memancing birahi dilarang oleh hadis tersebut apalagi telanjang yang sejak awal dimaksudkan sebagai memancing birahi. Oleh karena itu, dengan kategori mafhum muwafaqah kedua hadis menunjuk pada dua hal penting lainnya, yaitu pertama, hadis telah mencakup larangan untuk mendesain produk-produk pornografi. Kedua, berisikan larangan untuk menonton, membaca dan menikmati produk-produk pornografi. Sejak awal dimaksudkan sebagai, atau berpotensi menjadi bahan pornografi dilarang.

Dalam konteks pornografi, kedua hadis di atas secara tersirat juga menunjukkan bahwa perempuan berpotensi sebagai objek yang dipandang laki-laki dan karena dalam konteks tulisan ini berpotensi sebagai objek pornografi, sedangkan hadis lain menyebutkan bahwa laki-lakipun berpotensi sama dengan perempuan. Hal itu, antara lain terungkap dalam hadis riwayat Ummi Salamah berikut: ${ }^{20}$

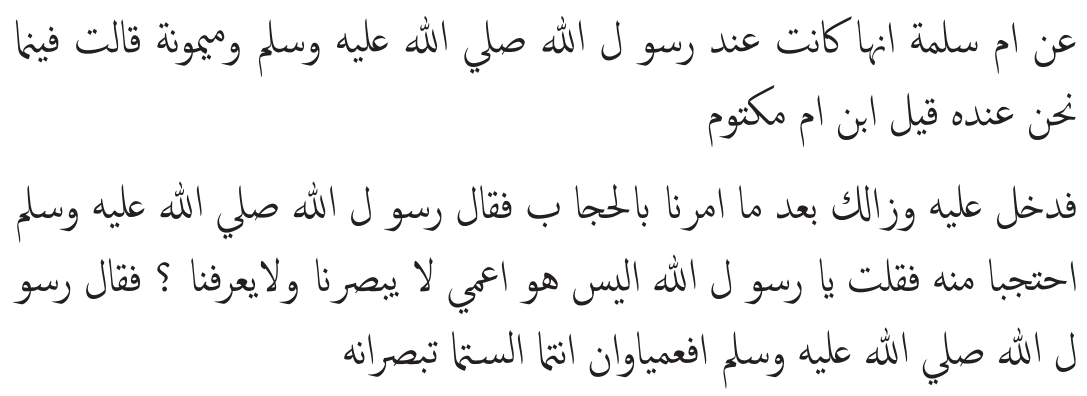

${ }^{19}$ Ibid, Hadis riwayat Abu Daud no. 201.

${ }^{20} \mathrm{Ibid}$, Hadis riwayat At-Turmudzi no. 442. 
Artinya:

Dari Ummi Salamah bahwa bersama Maimunah berada dirumah Rasulullah Saw. Ummi Salamah berkata: tatkala kami menyertai Nabi datanglah Abdullah ibn Ummi Maktum untuk menemui beliau. Kejadian itu setelah kami (perempuan) diperintah untuk berjilbab. Bersabdalah Nabi Saw "berhijablah kalian berdua dari Ibnu Ummi Maktum!”. Lalu aku berkata: wahai Rasulullah bukankah dia tunanetra (sehingga) dia tidak memandang dan mengetahui (keberadaan) kami? Rasulullah menjawab: benar dia tunanetra tetapi bukankah kamu berdua melihatnya”. (HR. At-Turmudzi)

Dua hadis terakhir di atas dikutip mufasir Ibnu Katsir ${ }^{21}$ ketika menafsirkan surat an-Nur/24: 30-31.

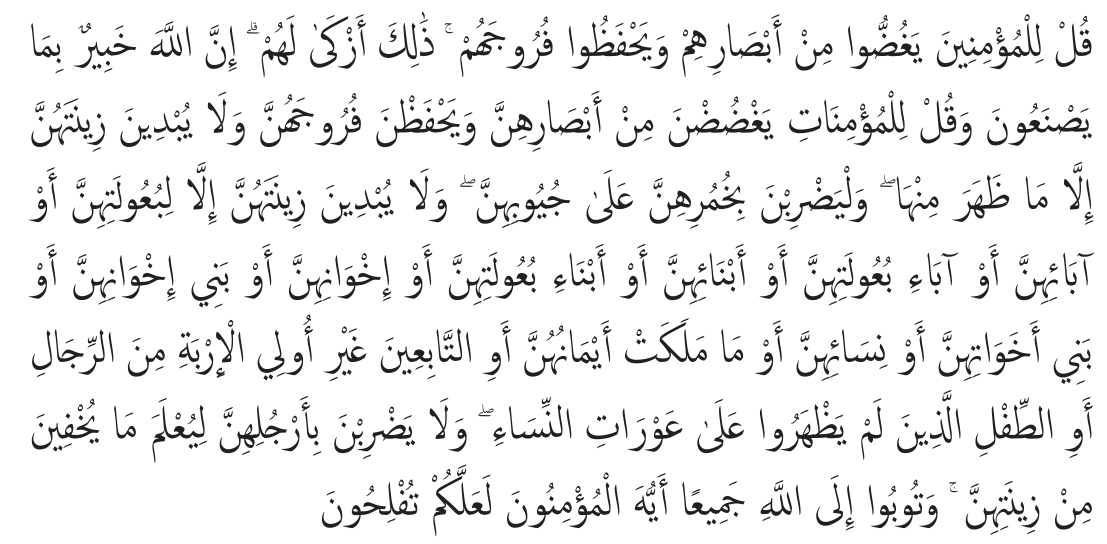

Artinya:

Katakanlah kepada orang laki-laki yang beriman: "Hendaklah mereka menahan pandanganya, dan memelihara kemaluannya; yang demikian itu adalah lebih suci bagi mereka, sesungguhnya Allah Maha Mengetahui apa yang mereka perbuat". Katakanlah kepada wanita yang beriman: "Hendaklah mereka menahan pandangannya, dan kemaluannya, dan janganlah mereka menampakkan perhiasannya, kecuali yang (biasa) nampak dari padanya. Dan hendaklah mereka menutupkan kain kudung kedadanya, dan janganlah menampakkan perhiasannya kecuali kepada suami

${ }^{21}$ Al-Imam Abul Fida Ismail Ibnu Katsir Ad-Dimasyqy, Tafsir al-Qur'an al-Adzim (Bairut: Dar al-Tayyibah,1420 H/1999), h. 284. 
mereka, atau ayah mereka, atau ayah suami mereka, atau putraputra mereka, atau putra-putra suami mereka, atau saudarasaudara laki-laki mereka, atau putra-putra saudara lelaki mereka, atau putra-putra saudara perempuan mereka, ... ${ }^{22}$

Dua hal yang dikandung ayat di atas, pertama, Islam menegaskan perintah dan panduan ayat ini kepada laki-laki dan perempuan. Di hadapan Allah swt. laki-laki dan perempuan setara dan keduanya disapa untuk menahan diri sekaligus bertanggungjawab atas perbuatannya, kedua, memperhatikan konteks historis (asbab al-nuzul) turunnya kedua ayat diatas sejatinya dimaksudkan sebagai panduan pergaulan antara laki-laki dan perempuan yang bukan mahram. Dengan tegas ayat tersebut menekankan dua hal prinsip sebagai pedoman yaitu; mengontrol pandangan dan mengontrol organ seksual. Karena itu, mengaitkan ayat diatas dengan pornografi sebagaimana dipaparkan pada definisi terdahulu terlihat bahwa aktivitas pornografi terkait erat dengan media visual atau yang dapat terlihat dan dibaca.

Memosisikan ayat dan hadis tersebut menjadi acuan dasar untuk mengatur pornografi tampak Islam bersikap hati-hati dalam menyikapi pornografi. Kehati-hatian ini terlihat dari semangat mengedepankan pencegahan dari pengobatan. Tindakan preventif dimaksud membatasi pandangan mata dan menjaga kemaluan. Dalam bingkai pornografi pencegahan dimaksud dengan cara; pertama, membuat regulasi yang ketat terhadap seluruh aspek kehidupan yang mengantarkan, dan berpotensi mengusung pornografi, baik dengan mengefektifkan perundang-undangan yang ada maupun menegaskan dan mendukungnya dengan undang-undang yang lebih tegas dan keras sanksinya. Langkah preventif semacam ini sejalan dengan pandangan yang menyebutkan bahwa maraknya pornografi di tengah masyarakat karena bebasnya produk berbagai media dalam memproduksi dan mengusung pornografi.

Pendapat kedua memandang bahwa pornografi diterima oleh masyarakat karena tipis dan minimnya kualitas keberagmaan masyarakat,

\footnotetext{
${ }^{22}$ Depertemen Agama RI, op.cit., h. 493.
} 
sehingga tidak mampu untuk menolak berbagai hal yang negatif termasuk pornografi. Menurut penulis, kedua pendapat tersebut tidak dapat dipisahkan satu sama lain. Faktor media berperan besar dalam mendangkalkan keberagamaan, sementara keberagaam yang tidak efektif menjadikan sesorang dengan mudah dirusak oleh pornografi. Lalu, Pendapat terakhir menyatakan bahwa keberagamaan yang tidak efektif sebagai salah satu sebab menyebarnya pornografi dibenarkan dengan pembacaan mafhum mukhalafah atas surah al-Ankabut/29: 45, yang mengaskan bahwa shalat yang efektif dapat mencegah kemungkaran. Dengan demikian, apabila pornografi sebagai salah satu ekspresi kemungkaran, yang muncul di tengah masyarakat merupakan indikasi tidak efektif keberagaam umat.

Pendapat pertama didukung oleh penelitian bahwa menyebarnya ponografi di tengah masyarakat Indonesia, khususnya kaum muda, bukan karena minimya kualitas moral mereka akan tetapi lebih besarnya kesempatan dan gencarnya paparan media. Menurut penelitian pada tahun 1980 an mengenai prilaku seksual remaja di kota kecil misalnya, Cirebon, Sukabumi, Jawa Barat menunjukkan bahwa sebahagian remaja telah melakukan hubungan seksual. Sementara penelitian di Jakarta pada tahun 1981 menunjukkan bahwa hal yang ditabukan remaja pada tahun 1950-an seperti berciuman dan bercumbu dibenarkan remaja pada tahun 1980-an. Penelitian laboratorium antropologi Universitas Indonesia pada tahun 1990-an menyebutkan bahwa separuh remaja pedesaan di Sumatera Utara dan Kalimantan Selatan, selain kerap menonton filmfilm yang menggambarkan seks di bioskop, mereka pun sering menonton film biru melalui video. Pada saat yang sama mereka pun sering membaca majalah dan produk sejenis yang secara vulgar memaparkan hubungan seksual layaknya suami istri yang sah. ${ }^{23}$

\section{Pendekatan Yuridis}

Fatwa MUI mengenai pornografi dan pornoaksi telah lama keluar.

${ }^{23}$ Lihat, Wawan Gunawan Abd. Wahid, Suara Muhammadiyah, SM/19 Jumadil Ula-3 Jumadiltsaniyah 1427 H/2006 M, h. 23 
Latar belakang lahirnya fatwa ini didasarkan beberapa pertimbangan diantaranya; sedemakin maraknya pornografi dan pornoaksi serta halhal lain yang sejenis dan tersebar secara luas dan bebas di tengah-tengan masyarakat dengan dukungan aneka ragam media. Dalam kenyatan, pornografi dan pornoaksi telah menimbulakn berbagai dampak negatif bagi umat Islam khususnya dan bangsa Indonesia pada umumnya, terutam dekadensi moral di kalangan genarasi muda. Misalnya; pergaulan bebas, perselingkuhan, aborsi, penyakit kelamin, kekerasan seksual dan seks menyimpang. Selain pertimbangan tersebut, fatwa ini juga didasari kajian mendalam beberapa ayat dalam Alquran dan hadis yang berkaitan dengan larangan pornografi dan pornoaksi, termasuk kaidah fikih, diantaranya.

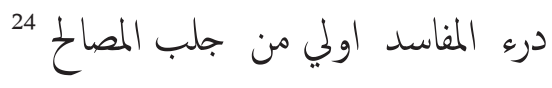

Artinya:

Menghindari mafsadat didahulukan daripada yang mendatangkan maslahat.

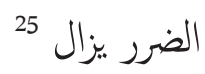

Artinya:

Sesuatu yang mendatangkan mudarat itu dihilangkan

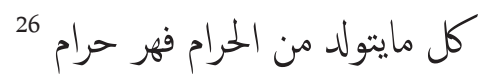

Artinya:

Setiap yang muncul/timbul dari sesuatu yang haram adalah haram.

Berdasarkan pertimbagan hal-hal tersebut, akhirnya pada tanggal 2 Agustus 2001 dengan nomor 287/2001 MUI Komisi Fatwa, menetapkan sebelas keputusan penting tentang pornografi dan pornoaksi. ${ }^{27}$

${ }^{24}$ Abdul Aziz Muh. Azam, Al-Qawaid al-Fiqhiyah (al-Qahirah: Dar al-Hadis, t.th.), h. 145 .

${ }^{25}$ Ibid, h. 138.

${ }^{26}$ Ibid. h.295.

${ }^{27}$ Departemen Agama RI, Himpunan Fatwa Majelis Ulama Indonesia (Jakarta: 
a. Menggambarkan secara langsung atau tidak langsung tingkah laku secara erotis, baik dengan lukisan, gambar, tulisan, suara, reklame, iklan maupun ucapan; baik melalui media cetak maupun elektronik yang dapat membangkitkan nafsu birahi adalah haram.

b. Membiarkan aurat terbuka dengan atau pakaian ketat atau tembus pandang dengan maksud untuk diambil gambarnya, baik untuk dicetak maupun divisualisasikan adalah haram.

c. Melakukan pengambilan gambar sebagaimana dimaksud pada angka 2 adalah haram.

d. Melakukan hubungan seksual atau adegan seksual di hadapan orang, melakukan pengambilan gambar hubungan seksual atau adegan seksual, baik terhadap diri sendiri maupun orang lain, dan melihat hubungan seksual atau adegan seksual adalah haram.

e. Memperbanyak, mendengarkan, menjual, membeli dan melihat atau memperlihatkan gambar, baik cetak maupun visual, yang terbuka auratnya atau berpakaian ketat atau tembus pandang yang dapat membangkitkan nafsu birahi, atau gambar hubungan seksual atau adegan seksual adalah haram.

f. Berbuat intim atau berdua-duaan (khalwat) antara laki-laki dengan perempuan yang bukan mahramnya, dan perbuatan sejenis lainnya yang mendekati dan mendorong melakukan hubungan seksual di luar pernikahan adalah haram

g. Memperlihatkan aurat yakni bagian tubuh antara pusar dan lutut bagi laki-laki serta seluruh bagian tubuh wanita selain muka,telapak tangan dan telapak kaki adalah haram, kecuali dalam hal-hal yang dibenarkan secara syari'i

h. Memakai pakaian tembus pandang atau ketat yang dapat memperlihatkan lekuk tubuh adlah haram

Proyek Pengadaan Sarana dan Prasarana Produk Halal Direktorat Jenderal Bimbingan Masyarakat Islam dan Penyelenggaraan Haji, 2003), h. 295 dan 303-304 
i. Melakukan suatu perbuatan dan atau suatu ucapan yang dapat mendorong terjadinya hubungan seksual di luar pernikahan atau perbuatan sebagaimana dimaksud angka 6 adalah haram.

j. Membantu dengan segala bentuknya dan membiarkan tanpa pengingkaran perbuatan-perbuatan yang diharamkan di atas adalah haram

k. Memperoleh uang, manfaat dan fasilitas dari perbuatan-perbuatan yang diharamkan di atas termasuk haram.

Demikian pula halnya Undang-Undang No. 44 Tahun 2008. Memperhatikan isi UU ini dan dilihat dari segi ajaran/hukum Islam terdapat beberapa pasal yang sejalan dengan ajaran Islam antara lain pasal 3 tentang tujuan UU ini untuk kemaslahatan masyarakat dan pasal XV tentang kewajiban setiap orang melindungi anak dari pengaruh pornografi. Akan tetapi pada pasal-pasal lain ada pasal yang tidak sejalan dengan hukum Islam. Oleh karena itu, UU ini sulit untuk dikatakan sebagai hukum Islam. Dalam persfektif akademik, ada tiga hal yang dapat menjadi paradigma analisis kritik terhadap UU ini, pertama, dari segi metode penemuan hukum, kedua, basis ideology dan ketiga, substansi hukum..$^{28}$

UU Pornografi lahir melalui metodologi penemuan hukum yang khas dalam demokrasi, yaitu hukum adalah ekspresi dari kehendak rakyat. Sebab dalam demokrasi kedaulatan ada di tangan rakyat. Kedaulatan adalah otoritas tertinggi yang bersifat absolut untuk mengeluarkan hukum atas segala perbuatan manusia. Dalam prakteknya, prinsip ini dilaksanakan oleh perlemen sebagai perwakilan rakyat, yang bertugas menyerap aspirasi dan kehendak masyarakat. Dalam melaksanakan tugasnya ini kriteria untuk mengambil pendapat parlemen berdasarkan suara terbanyak.

Dalam Islam, kedaulatan bukan di tangan rakyat, akan tetapi di tangan syari'ah, yang membuat hukum bukan manusia, akan tetapi Allah

\footnotetext{
${ }^{28}$ Lihat http://senopatiarthur.wordpress.com.
} 
swt. Manusia hanya menggali hukum dari wahyu, bukan membuat hukum sendiri, dengan sumber selain wahyu. Selain itu, yang dimiliki oleh umat Islam adalah kekuasaan, bukan kedaulatan. Kekuasaan adalah otoritas untuk melaksanakan UU. Kekuasaan dalam Islam adalah di tangan umat. Meskipun kekuasaan dalam Islam dan demokrasi sama dipegang oleh manusia, tetapi kekuasaan dalam Islam berbeda dengan demokrasi. Dalam Islam, kekuasaan ditujukan untuk menerapkan hukum syariat Islam, sedangkan dalam demokrasi kekuasaan ditujukan untuk menerapkan hukum buatan manusia, bukan hukum Islam. Secara kelembagaan, hukum (UU) untuk publik dalam demokrasi dilegislasikan oleh parlemen. Sedangkan dalam Islam hukum untuk publik dilegislasikan oleh khalifah (kepala negara) bukan oleh wakil rakyat. Dengan kata lain, secara metodologi, yaitu dari segi kedaulatan, lembaga legislasi, dan kriteria pengambilan pendapat, UU Pornografi bertentangan dengan Islam.

Kritik atas UU Pornografi ini adalah ketidakjelasan basis ideologi yang digunakan. UU ini mencoba mengatur masalah pornografi untuk seluruh masyarakat Indonesia yang faktanya memeluk ragam agama atau keyakinan. Basis ideologi UU Pornografi ini nampaknya adalah ide pluralisme yang mencoba mengakomodasi segala ragam agama atau keyakinan. Padahal masalah pornografi dalam beberapa bagian atau seluruhnya, seperti menyangkut masalah pakaian, sangat terkait dengan keyakinan seseorang. Misalnya, pakaian seorang Muslim tentu berbeda dengan pakaian seorang Hindu. Dengan demikian aspek pornografinya pun juga mestinya berbeda. Ketelanjangan bahu bagi seorang perempuan Hindu mungkin tidak masalah karena demikianlah ketentuan peribadatan di dalam Pura mereka, tetapi tidak demikian halnya dengan seorang Muslimah. Karena itu, tidak jelasnya basis ideologi yang digunakan, definisi tentang pornografi dalam UU ini juga menjadi kabur. Bila dikatakan pornografi adalah materi seksualitas yang melanggar nilai-nilai kesusilaan masyarakat, pertanyaannya, masyarakat yang mana? Bila sejak definisi pornografi sudah kabur, maka tentu pengaturan berikutnya juga menjadi tidak jelas. Ketidakjelasan seperti demikian yang mengundang reaksi, khususnya dari komunitas non- 
Muslim di Bali maupun daerah lain. Mereka khawatir UU ini akan mengeliminir sebagian keyakinan mereka.

Berbeda halnya bila UU semacam ini didasarkan pada basis ideologi Islam, yaitu disusun berdasarkan ketentuan syariah Islam. Maka definisi tentang pornografi dengan mudah dibuat. Dan pasti tidak akan menyinggung agama lain, karena masalah-masalah yang terkait dengan keyakinan dikembalikan kepada agama masing-masing, baik yang berkaitan dengan tata peribadatan maupun berpakaian. Justru di sinilah pentingnya penerapan syariat Islam di tengah masyarakat. Syariat akan memberikan pengaturan tentang berbagai hal secara jelas, tegas dan konsisten untuk seluruh masyarakat. Tetapi sekaligus tetap menghargai adanya perbedaan keyakinan agama. Dengan cara tersebut, kerahmatan yang dijanjikan dari penerapan syariah Islam itu bisa diwujudkan.

\section{Kritik Substansi Hukum}

Kritik berikutnya terhadap UU Pornografi, adalah dari segi substansi, yaitu materi hukum yang termuat dalam pasal-pasal UU Pornografi. Banyak pasal-pasal yang perlu dikritisi dari perspektif Islam. Di antaranya:

Pertama: Judul/Nama UU. UU ini telah mengalami perubahan, yakni semula RUU Anti Pornografi dan Pornoaksi (RUU APP) menjadi RUU Pornografi (RUU P), dan akhirnya disahkan sebagai UU Pornografi. Perubahan nama ini jelas kontraproduktif sekaligus kontradiktif (bertentangan) dengan semangat awal untuk memberantas dan menghapus segala bentuk kepornoan. Penghapusan kata anti pada judul RUU memberikan kesan, bahwa RUU ini hanya akan mengatur pornografi, dan bukan berniat menghapuskannya. Adapun penghapusan kata pornoaksi mengandung pengertian, bahwa yang diatur hanyalah pornografi (media/sarana yang mengandung unsur kepornoan), sementara pornoaksi (perilaku porno seperti cara berpakaian yang mengumbar aurat ataupun tindakan porno lainnya di tempat umum) tidak diatur atau dengan kata lain dibiarkan. Karena itu, alih-alih pornografi 
dan pornoaksi akan lenyap, dengan disahkannya RUU Pornografi ini menjadi UU, pornografi dan pornoaksi mungkin malah akan mendapat legitimasi dan semakin berkembang. Kemudian, dalam perspektif Islam, pornografi dan pornoaksi adalah kemungkaran yang harus dilenyapkan. Bukan hanya dibuatkan regulasi, apalagi dilegalisasi.

Kedua: Pasal-Pasal Yang Cacat dan Kontradiktif Dengan Islam. Banyak pasal UU Pornografi yang cacat dan sekaligus bertentangan dengan Islam. Misalnya: (1) Definisi Pornografi. Dalam pasal 1 ayat 1 disebutkan: Pornografi diartikan sebagai: adalah materi seksualitas yang dibuat manusia dalam bentuk gambar, sketsa, ilustrasi, foto, tulisan, suara, bunyi, gambar bergerak, animasi, kartun, syair, percakapan, gerak tubuh, atau bentuk pesan komunikasi lain melalui berbagai bentuk media komunikasi dan/atau pertunjukan di muka umum, yang dapat membangkitkan hasrat seksual dan/atau melanggar kesusilaan masyarakat.

Pasal ini mengandung sejumlah masalah termasuk dalam cakupan pornografi menurut UU ini hanyalah materi seksualitas yang mengandung 2 (dua) unsur, yaitu : (1) yang dapat membangkitkan hasrat seksual, dan/atau (2) melanggar nilai-nilai kesusilaan dalam masyarakat. Pengertian ini masih belum konkret sehingga bisa menimbulkan macam-macam penafsiran. Misalnya, Apa batasan 'membangkitkan hasrat seksual' itu dan siapa yang berhak menentukan kriterianya? Apa yang dijadikan sebagai standar nilai-nilai kesusilaan dalam masyarakat? Masyarakat yang mana? Bukankah di Indonesia terdapat banyak suku dan budaya yang memiliki standar nilai kesusilaan yang berbeda-beda? Dalam pasal-pasal berikutnya dijelaskan beberapa jenis materi pornografi yang dilarang. Namun, materi pornografi yang dilarang itu sangat sempit dan sedikit sehingga memberikan peluang bagi lolosnya banyak materi pornografi di masyarakat.

Pengertian Pornografi dalam UU ini juga mencakup 'pertunjukan di muka umum. Tampaknya pengertian tersebut berusaha mencakup wilayah 'pornoaksi'. Akan tetapi, jangkauannya amat sempit karena yang disebutkan hanya 'pertunjukan' saja. Berbagai tindakan lain yang 
termasuk dalam 'pornoaksi' (seperti cara berpakaian yang mengumbar aurat di tempat umum, berpelukan dan berciuman di tempat umum, dan lain lain) tidak dapat dijerat dalam UU ini. Dalam perspektif Islam, Islam tidak secara jelas memberikan pengertian tentang pornografi. Namun demikian, Islam memiliki konsep tentang aurat yang jelas dan baku. Aurat laki-laki, baik terhadap laki-laki maupun terhadap wanita adalah antara pusar dan lutut. Sementara aurat wanita terhadap lakilaki (bukan suami dan bukan mahramnya) adalah seluruh tubuh kecuali wajah dan dua telapak tangannya. Di samping itu, pakaian yang dikenakannya sudah ditentukan yakni: jilbab dan kerudung, yang menutupi seluruh tubuh kecuali wajah dan telapak tangan.

Aurat tersebut wajib ditutup dan tidak boleh dilihat kecuali orang yang berhak, terlepas terlihatnya aurat itu dapat membangkitkan birahi atau tidak. Dalam Islam, yang menjadi kriteria adalah aurat itu tertutup atau tidak, bukan hasrat seksual bangkit atau tidak. Islam juga melarang beberapa tindak yang berkaitan dengan tata pergaulan pria dan wanita. Di antaranya Islam melarang tabarruj (berhias berlebihan di ruang publik), berciuman, berpelukan bercampur-baur antara pria dan wanita, berkhalwat dengan wanita bukan mahram, dan segala perbuatan yang dapat mengantarkan perzinaan. Konsep ini jauh bermartabat daripada konsep mengenai pornoaksi. (2) Masalah Larangan. Ada sejumlah larangan dalam UU ini yang juga bermasalah. Dalam pasal 4 ayat 1 , misalnya, disebutkan: Setiap orang dilarang memproduksi, membuat, memperbanyak, menggandakan, menyebarluaskan, menyiarkan, mengimpor, mengekspor, menawarkan, memperjualbelikan, menyewakan, atau menyediakan pornografi yang memuat: (a) persenggamaan, termasuk persenggamaan yang menyimpang, (b) kekerasan seksual, (c) masturbasi atau onani, (d) ketelanjangan atau tampilan yang mengesankan ketelanjangan, atau (e) alat kelamin. Menurut pasal ini, materi seksual yang dikategorikan sebagai pornografi hanya menyangkut lima perkara, yang semuanya hanya berkisar pada kelamin saja (persenggamaan, kekerasan seksual, masturbasi, ketelanjangan, dan alat kelamin). Ini berarti, materi pornografi selain yang disebutkan itu tidak termasuk dalam kategori pornografi yang dilarang. Kesimpulan ini juga 
sejalan pasal 13 ayat 1 .

Dengan demikian, mempertontonkan beberapa anggota tubuh lainnya yang juga dapat membangkitkan hasrat seksual seperti paha, pinggul, pantat, pusar, perut dan payudara perempuan tidak termasuk dalam pornografi yang dilarang. Kategorisasi demikian tentu sangat membahayakan dan merusak kehidupan masyarakat. Akan muncul banyak produk dan perbuatan porno secara bebas tanpa takut diusik siapapun karena telah mendapatkan legalisasi dari UU ini. Perempuan yang terbiasa mempertontonkan beberapa anggota tubuhnya seperti rambut, paha, pinggul, pantat, pusar, perut, dan payudara, misalnya, menjadi semakin merasa aman. Demikian juga berbagai tindakan yang membangkitkan hasrat seksual seperti tarian erotis, berciuman, berpelukan, dan sebagainya.

Dalam perspektif Islam, rumusan pasal mengenai pornografi yang dilarang dalam UU ini pada pasal 4 ayat 1 sangat bertentangan dengan Islam. Dalam Islam, jangankan alat kelamin dan ketelanjangan, aurat saja tidak boleh dipertontonkan di muka umum. Bukan hanya persenggamaan, berbagai tindakan yang terkategori sebagai muqaddimah alzina (pendahuluan zina) juga dilarang dilakukan di muka umum, apalagi dilakukan oleh bukan pasangan suami-istri. Ketentuan itu berlaku umum. Semua perbuatan yang membuka aurat di muka publik dikategorikan sebagai tindakan terlarang. Perkecualian hanya disandarkan terhadap ketentuan syara', seperti dalam kesaksian, pengadilan dan pengobatan. (3) Masalah Pembatasan. Dalam UU ini juga ada sejumlah pembatasan yang juga bermasalah. Dalam pasal 14, misalnya, disebutkan: Pembuatan, penyebarluasan, dan penggunaan materi seksualitas dapat dilakukan untuk kepentingan dan memiliki nilai: (a) seni dan budaya (b) adat istiadat, dan (c) ritual tradisional.

Islam menegaskan bahwa, semua ketentuan syariah berlaku umum kecuali ada dalil syar'i yang memperbolehkannya. Seni budaya, adat istiadat, dan ritual tradisional tidak termasuk dalam alasan yang dibenarkan syar'i untuk membolehkan pornografi dan pornoaksi yang dilakukan di tengah kehidupan masyarakat. Dengan demikian, pem- 
batasan/perkecualian pada 3 aspek tersebut sangat absurd dan bertentangan dengan Islam. Pornografi dan Pornoaksi pada 3 aspek itu tetap haram. Mengapa? Sebab tidak ada dalil dari Alquran atau sunnah yang mengecualikannya. Mengecualikan atas dasar akal atau kemaslahatan adalah batil menurut Islam. Selain itu, Islam mewajibkan kaum Muslimin, terutama penguasa untuk menyampaikan dakwah dan bimbingan terhadap masyarakat yang belum mengenal Islam, misalnya masyarakat yang masih mengenakan koteka. Bukan membiarkannya terus dalam penyimpangan. Karenanya, tugas pemerintah adalah melakukan penyuluhan dan penyadaran pada masyarakat yang memiliki adat-istiadat dan ritual tradisional yang menyimpang.

\section{Penutup}

Berdasarkan uraian sebelumnya, maka penulis dapat menarik beberapa kesimpulkan, sebagai berikut;

1. Pornografi dan pornoaksi pada dasarnya ada dan dikenal sejak zaman dahulu kala bahkan setua dengan sejarah peradaban umat manusia di dunia. Beberapa hal yang menjadi sarana penyebarannya, antara lain: pertama, internet melalui berbagai situs yang menggambarkan dan membuat narasi tentang kegiatan seksual para artis dan publicfigure lainnya sampai ke masyarakat awam dengan berbagai aktivitas seksual baik yang normal maupun abnormal (homoseks, lesbian dan lain-lain). Kedua, televisi melalui berbagai sinetron, kisah seputar selebriti, music dangdut yang menyuguhkan penampilan yang seronok. Ketiga, tabloid dan majalah yang memajang gambar-gambar setengah telanjang sampai yang telanjang penuh dengan berbagai cerita mulai yang isapan jempol sampai kisah sungguhan seputar seks.

2. Pornografi dan pornoaksi dalam perspektif hukum Islam adalah terlarang, hal ini jelas secara normatif berdasarkan beberapa ayat dalam Alquran dan beberapa hadis Rasulullah Saw yang tegas melarang. Selain itu, juga ketentuan dalam Fatwa MUI tanggal 22 Agustus 2001 No. 287 Tahun 2001 dengan jelas dan tegas meng- 
haramkan pornografi dan pornoaksi dengan segala bentuknya. Undang-Undang Pornografi yang telah disahkan pada 30 Oktober 2008 yang lalu dilihat dari segi; metode penemuan hukum, basis ideologi dan substansi hukum, terdapat beberapa pasal atau ketentuan yang tidak sejalan dengan ajaran Islam. Karena itu UU ini tidak dapat disebut hukum Islam.

\section{Daitar Pustaka}

Alquran dan Terjemahnya

CD ROOM. Hadis Kutub Tisả .

Departemen Agama RI. Himpunan Fatwa Majelis Ulama Indonesia. Jakarta: Proyek Pengadaan Sarana dan Prasarana Produk Halal Direktorat Jenderal Bimbingan Masyarakat Islam dan Penyelenggaraan Haji, 2003.

Departemen Pendidikan Nasional. Kamus Besar Bahasa Indonesia. Edisi III.Jakarta: Balai Pustaka, 2005.

al-Dimasyqy, Al-Imam Abul Fida Ismail Ibnu Katsir. Tafsir al-Qur'an alAdzim. Bairut: Dar al-Tayyibah,1420 H/1999.

al-Gazali, Shaykh Muhammad. A Thematic Commentary on The Qu'an, Kuala Lumpur-Islamic Book Trust, The International Institute of Islamic Thaught, 2000.

Gunawan, Wawan. Suara Muhammadiyah. Jogjakarta: 1427 H/2006 M. Hamka, Tafsir Al-Azhar. Juz VIII. Cet.III. Jakarta: PT.Pustaka Panjimas, 1999.

Http://senopatiarthur.wordpress.com.

Majelis Tarjih dan Pengembangan Pemikiran Islam, Pornografi dan Pornoaksi. Edisi V. Jogyakarta, 2003. 
Muhammad Azam, 'Abdul Aziz. Al-Qawaid al-Fiqhiyah. Al-Qahirah: Dar al-Hadis, t.th.

al-Maraghi, Ahmad Musthafa. Tafsir al-Maraghi. Mesir: Mustafa al-Babi al-Halabi, 1394 H /1974 M.

Sa'abah. M. Perilaku Seks Menyimpan dan Seksualitas Kontemporer Umat Islam. Jakarta: UI Press, 2001.

Shihab, M. Quraish. Tafsir al-Mishbah Vol. 11. Cet. V; Jakarta: Lentera Hati, 2006. 